DOI: https://doi.org/10.34069/AI/2021.46.10.26 How to Cite:

Baliun, O., Tomina, K., Fisenko, T., Smola, L., \& Lytvyn, A. (2021). Psychosemantic interpretation of media space video advertising for brands (Mcdonald's, Coca-Cola, Nestlé, Roshen). Amazonia Investiga, 10(46), 259-272. https://doi.org/10.34069/AI/2021.46.10.26

\title{
Psychosemantic interpretation of media space video advertising for brands (Mcdonald's, Coca-Cola, Nestlé, Roshen)
}

\section{ПСИХОСЕМАНТИЧНЕ ОСМИСЛЕННЯ МЕДІАПРОСТОРУ ВІДЕОРЕКЛАМИ БРЕНДІВ (MCDONALD'S, COCA-COLA, NESTLÉ, ROSHEN)}

Received: September 10, 2021

\section{Abstract}

The relevance of the research topic is due to the need to increase the evidence-based studies on enhancing the development effectiveness of audiovisual advertising message, which creates an urgent demand for further scholarly elaboration of such a complex phenomenon as psychosemantic analysis of video advertising. The purpose of the study is to identify opportunities to increase efficiency of audiovisual communication by conducting the psychosemantic study of the perception of video advertising of brands. The methodological basis of the study is a set of marketing, sociological and psychological methods. In particular, the focus group, survey, semantic differential and George Kelly's repertory grid methods were chosen to study the psychosemantic space of the target audience. Correspondingly, the qualitative results of psychosemantic influence of video advertising on consumer consciousness were achieved through mathematical calculations and

\author{
Accepted: October 302021 \\ Written by: \\ Baliun Oksana ${ }^{99}$ \\ https://orcid.org/0000-0002-7676-9049 \\ Tomina Kristina ${ }^{100}$ \\ https://orcid.org/0000-0003-4453-6125 \\ Fisenko Tetiana ${ }^{101}$ \\ https://orcid.org/0000-0003-1837-0117 \\ Smola Lidiya ${ }^{102}$ \\ https://orcid.org/0000-0003-3780-5163 \\ Lytvyn Aelita ${ }^{103}$ \\ https://orcid.org/0000-0003-3897-6175
}

\section{Анотація}

Актуальність теми дослідження зумовлена необхідністю збільшення науково обгрунтованих досліджень щодо підвищення ефективності розробки аудіовізуального рекламного повідомлення, що формує нагальну потребу подальшого наукового осмислення такого складного феномену як психосемантичний аналіз відеореклами. Метою цього дослідження $є$ визначення напрямків підвищення ефективності аудіовізуальної комунікації шляхом проведення психосемантичного дослідження сприйняття відеореклами брендів. Методологічної основою дослідження $\epsilon$ сукупність маркетингових, соціологічних та психологічних методів. Зокрема, для дослідження психосемантичного простору цільової аудиторії було обрано методи фокусгрупи, опитування, семантичного диференціала та метод репертуарних решіток Дж. Келлі. У реузльтаті, шляхом

\footnotetext{
${ }^{99} \mathrm{PhD}$, Associate professor of the Department of Publishing and Editing National Technical University of Ukraine Igor Sikorsky Kyiv Polytechnic Institute, Ukraine.

${ }^{100}$ Master of the Department of Publishing and Editing National Technical University of Ukraine Igor Sikorsky Kyiv Polytechnic Institute, Ukraine.

${ }^{101} \mathrm{PhD}$, Associate professor of the Department of Publishing and Editing National Technical University of Ukraine Igor Sikorsky Kyiv Polytechnic Institute, Ukraine.

${ }^{102}$ Doctor of Political Sciences, professor of the Department of Publishing and Editing National Technical University of Ukraine Igor Sikorsky Kyiv Polytechnic Institute, Ukraine.

${ }^{103} \mathrm{PhD}$, Associate professor of the Department of Publishing and Editing National Technical University of Ukraine Igor Sikorsky Kyiv Polytechnic Institute, Ukraine.
} 
graphic illustrations. The study presents the results of psychosemantic research of video commercials, which highlight the features of their psychosemantic perception by the consumer. The emphasis is placed on the fact that the previous experience, knowledge and personal values of target audience representatives have an impact on their perception of different types of video advertising of the brand within one advertising campaign. The recommendations for improving the efficiency of audiovisual communication have been developed.

Key Words: advertising, George Kelly's repertory grid method, promotional video, psychosemantic space, semantic differential method.

\section{Introduction}

The modern dynamic development of the advertising market involves the use of the latest methods of psychological influence on consumer opinion. The visual values as the main part of visual communication are an important and accessible method of information distribution around the world. Consequently, video advertising has significant importance among other types of visual messages as it includes not only the active development of globalization processes, but also a strong psychological effect that it has on the human consciousness.

According to the results of the annual advertising effectiveness monitoring conducted by the global Search Engine Journal SEO community and the American multinational company Cisco, the video content accounts for $80 \%$ of all web traffic as of 2019, although this figure is expected to triple in 2021 (Chandrasekar, 2018). Additionally, according to the IAB Video Advertising Spend Report summary, the digital advertising costs are increasing, in particular, they grew by $25 \%$ in 2020 and amount to almost \$ 28 million right now (The Interactive Advertising Bureau, 2020). So far, the number of low-quality and uninteresting advertisements, including video advertising, is constantly growing. The main elements of poor advertising include the following problems, such as partial or complete inconsistency of advertising content with the recipient's expectations, the lack of emotional content (careless presentation of information), the lack of potentially necessary offer to the consumer. математичних розрахунків та графічних ілюстрацій, було отримано якісні результати психосемантичного впливу відеореклами на споживацьку свідомість. В дослідженні представлені результати психосемантичного дослідження рекламних відеороликів, які дозволили виявити особливості їх психосемантичного сприйняття споживачем. Акцентовано увагу на тому, що на сприйняття представників цільової аудиторії різних видів відеореклами бренда, у межах однієї рекламної кампанії, вливає їхній попередній досвід, знання та система цінностей. Розроблено рекомендації щодо підвищення ефективності аудіовізуальної комунікації.

Ключові слова: відеореклама, метод репертуарних решіток, метод семантичного диференціалу, реклама, психосемантичний простір.

The application of psychosomatic analysis of communication messages at the stage of their development is considered to be the solution to this problem. The context is filled with meaning through the semantic analysis, and beside that, psychosemantics makes it possible to correctly direct this symbolic, sign-oriented, verbal or graphic message to the masses.

The relevance of the research topic is due to the deficiency in thorough and systematic scientific works, which would analyze the theoretical and practical aspects of psychosematic perception of visual communication. The lack of scientifically valid recommendations for improving the effectiveness of the audiovisual advertising message development creates an urgent need for further scholarly comprehension of such a complex phenomenon as psychosemantic analysis of video advertising. The purpose of the study is to identify opportunities to increase efficiency of audiovisual communication by conducting the psychosemantic study of the perception of commercial, corporate and social video advertising of brands.

\section{Literature review}

Psychosemantics as a scientific phenomenon and its psychological impact on human consciousness have been considered by such researchers as V. Petrenko, O. Mitina (Petrenko, \& Mitina 2020), T. Kosarevskaya, R. Kutkyna (Kosarevskaya, \& Kutkyna, 2009), O. Lipovaya (Lipovaya, 2015), O. Yu. Smirnova, V. P Serkin,. (Smirnova,\& Serkin, 2020). 


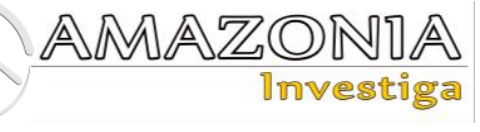

Theoretical aspects of the psychology methods' influence in social communications and particularly sign-semantic analysis as the advertising communication optimizer is considered by M. Dushkina (Dushkina, 2021). O. Sosniuk (Sosniuk, 2018) singled out the basic constructs as the part of the innovative brand concept's semantic space. According to the author, such consumer qualities as sensitivity to innovation, willingness to take risks, creativity and conformity are significantly correlated with a positive perception of innovative brands. H. Horner (Horner, 2018) explores the impact of video advertising on consumer's psychology. M. Nazarov, M. Papantimu (Nazarov, \& Papantimu (2009) possibilities analysis research based on the semiotics and psychosemantics methods combination reveals the usage opportunitiesof psychosemantic color's testing as a factor in visual advertising perception. G. Antonides, F. W. Raaij (Antonides, \& Raaij, 1999) study consumer behavior, also taking into account economic, psychological and sociological aspects of influence. The general role of emotions and other psychological aspects in influencing the individual's opinion have been formulated by scholars such as E. du Plessis, (du Plessis, 2009), S. Acharya, S. Shukla (Acharya, \& Shukla 2012).

On the basis of the scientific research the attempt to deepen the study of the video advertising impact on consumers was made, 3articularly by expanding the research material (different types of advertising) in three different age target audiences. Using focus group methods, semantic differential and J. Kelly's repertoire grids, we have investigated the psychological perception of different promotional videos types' by the target audience in the psychosemantic brands' space. During the study we have confirmed our assumption that the target audience's perception of different brand's video advertising types within one advertising campaign, is influenced by their previous experience, knowledge and values system.

It should be noted that, the academic works of such scholars as A. Kukuliar, A. Grishina, O. Chinarova \& Achina (Kukuliar et al., 2019), L. A. Maksimova, A.V. Smirnov, N. N. Vasyagina (Maksimova, Smirnov, \& Vasyagina, 2019) are devoted to certain aspects of psychosemantic analysis of audiovisual communication perception.

However, the research activities on such a narrow topic as the study of the psychosemantic space of brands on the example of video advertising require further development.

\section{Methodology}

In their studies, the authors used a comprehensive interdisciplinary approach that combines both general-scientific and specialized methods of information processing. In particular, the methods such as analysis, classification and generalization were applied. The methods of marketing, sociological and psychological research were employed to identify and study the target audience selected for the analysis of brand videos.

The focus group method was chosen to analyse the psychosemantic space of the target audience. The survey (questionnaire) method was chosen due to its interactivity and variability.

The semantic differential is the next method that was chosen for the analysis of the psychosemantic space of consumer pattern. As noted by American scientists W. Chin, Johnson, $\&$ N. Schwarts, A. (2008), one of the advantages of this approach is its complexity and ease of management.

George Kelly's repertory grid method was additionally used in order to increase reliability of potential results. It includes three types of grids, that is, rank, implicative and evaluative. The third type was used during the study because the evaluative grid has a similar structure to the semantic differential, and that, in turn, can increase the reliability of the analysis results. The formalization method allowed to unify the structure of the obtained results in the sign model with the help of mathematical symbols, graphs, schemes, tables.

Four companies that are either food manufacturer or work in food service industry, such as McDonald's, Coca-Cola, Nestlé, Roshen, were selected as the objects of psychosomatic research about the impact of advertising videos on Ukrainian consumers. In particular, the first three positions are occupied by brands that took the leading position in the ranking of the TOP 100 richest companies according to BrandZ (the world's largest database of brands), namely McDonald's, Coca-Cola, Nestlé (Kantar Group and Affiliates, 2020). In fact, it was decided to take one Ukrainian corporation called Roshen, which occupies the 27 th place in the TOP-100 ranking in the world market among confectionery products, for a more detailed analysis (Candy Industry, 2020). 
The choice of advertising videos of these brands was based not only on their novelty (selected messages have broadcast on Ukrainian television for the last 2 years), but the variety of advertising messages was also an important criterion. Based on the history of advertising campaigns of global companies, such types of video advertisement as commercial, social and corporate were selected.

In particular, the following sample of videos was identified for analysis: Roshen commercial and corporate advertising, Coca-Cola corporate and social advertising, McDonald's corporate and social advertising, Nesquik commercial and corporate advertising. In total, 8 advertising videos were selected for the study.

The first stage of our study is to identify the target audiences.

The video advertising of the Nesquik product from Nestlé company, which was broadcast on Ukrainian television from 2018 to 2019 , will be primarily considered (VideoAds, 2018). The main characters of this advertisement are children who lead an active lifestyle because they drink Nesquik cocoa beverage. The target audience of this advertisement can be divided into primary (children) at the age of 4-15 years and secondary (parents) at the age of 30-45 years. According to the segments of the VALS model, the primary target audience should be classified as «strivers», which is to say that the child's lifestyle is directly proportional to the aspiration to imitate their peers in desires and ideas, and what is more, they have a low level of economic and social resources.

The video advertising of McDonald's, American foodservice operator, was chosen for further study. As part of its social campaign, the brand has developed a series of videos with the hashtag \#без_батьків_ніяк (we cannot do without parents), where the main idea is that when buying "the palms of happiness" or charitable souvenirs, the members of the general public invests in creating and maintaining the family rooms in Ukrainian hospitals (McDonald's Ukraine, 2020).Its target audience covers an older age group of 18-55 years. In terms of VALS segments, the «experiencers», that is the newest segment with an average age of about 25 years, can be considered the main target audience for the McDonald's video advertising.

The third video clip of Coca-Cola brand is the latest among the entire advertising sample. The main idea of the advertising message is based on the current problem, namely on pandemics and quarantine in the world (Coca-Cola Journey Ukraine, 2020).

Thus, the main target audience of the advertising video is men and women at the age of 20-45. According to the VALS model, the segmentation of the target audience demonstrates that the direct viewers of the advertising video are the category of «makers», and practicality and selfsufficiency are important for them.

The last video is an advertisement of the Ukrainian confectionery brand Roshen. The video advertising is purely commercial in nature and it describes its product as the best among all others with the slogan "Roshen dark chocolate is the first after yourself” (Bart fink, 2019). The target audience of the Roshen advertising video is men and women at the age of 30-55. It can be defined by such a segment as «believers», because they all share one characteristic, that is, the motivation by ideals.

The morning media project «Morning with Ukraine» of the national Ukrainian TV channel «Ukraina» («Ukraine») was chosen to study corporate advertising. The main characters of the first corporate advertising are the TV presenter of the morning project L. Rebryk and her eldest daughter Diana, who is 8 years old (Morning with Ukraine, 2020). If the message of commercial advertising is clearly aimed at children in order to encourage them to taste the products, the main goal of corporate advertising is, on the contrary, to attract parents. Since mothers are mainly concerned with the nutrition of their children, the target audience of the selected video is believed to be women at the age of 30-45. The audience of the Nesquik video clip can be classified to such segments as «thinkers» and «achievers».

The next video was developed specifically for the Coca-Cola brand that sponsored the morning program in 2019. The main goal is to tell Ukrainian viewers about the effective social activities of the brand, especially about the introduction of a training course for external independent testing of children from boarding schools together with the public organization «Osvitoria» (Osvitoria, 2019). The primary audience of this campaign is the children at the age of 14-16 who do not have parents and are studying in a boarding school, while the secondary audience is people at the age of 14-34 who are in need of brand loyalty awakening on the basis of the socially active performance of the company. VALS segmentation demonstrates that the target audience has the characteristics of 


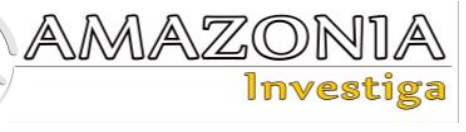

«believers», namely a low-resource group of consumers who are motivated by certain ideals.

The third video from McDonald's sponsor was shot directly within the institution itself. The main character is a journalist of the project, who informs the audience about the social initiative of the «The palm of happiness» brand, thanks to which family rooms for parents are being built in Ukrainian children's hospitals. The core of the target audience is men and women at the age of 8 -40. In terms of segments, the audience is divided into «innovators» and «thinkers».

The last corporate video clip of the Ukrainian company Roshen demonstrates the construction and presentation of a new modern zoo in Cherkasy. Thus, the target audience of the video clip is men and women at the age of 25-55. According to the VALS model, the motivation to buy something of this category of society is based on the desire for self-expression. The audience segmentation reveals believers' characteristics of predictability and modesty (age of 30-55).

After defining the target audience for each advertising message, the second stage of our study is to form three focus groups that correspond to the above-mentioned results of target market segmentation.

Thus, it was found by analyzing the target audience of advertising videos that the market social group is divided into three segments, such as children, adolescents and adults. The mathematical calculation of the average ratio of each group is applied in order to select the specific age ranges for the greatest efficiency of the analytical process. The arithmetic mean value is calculated by adding all the numbers and dividing their sum by their quantity. As the result, the following focus groups for future research were identified:

1) children at the age of 9-11 years old (focus group №1);

2) teenage orphans at the age of 14-16 years old (focus group №2);

3 ) adults at the age of 25-45 years old (focus group №3).

The focus group № 1 consists of children aged 9-11 years old, and all of them attend school of I-III levels №70 in Shevchenkivskyi District
(Kyiv). The number of respondents in this group is 8 people. The focus group is in exact accordance with the target audience of the Nesquik advertising video, so the survey results have the highest percentage of effectiveness. The focus group №2 consists of teenage orphans aged 14-16 years old. The survey was conducted in a family-type orphanage situated in the village of Kriukivshchyna, Kyiv region. The number of respondents to the study is 8 people. The peculiarities of the target segment, which were considered in the second section, are also taken into account, as adolescents are currently going to enter higher educational establishment.

The focus group №3 consists of people aged 25-45 years old. The people of different social status, with different views on life, values and principles constitute the structure of this segment, but they are all united by consumer interest. The group also includes two experts in the field of psychology, in particular, A. Lytvyn, a candidate of historical sciences, practicing psychologist and image maker, as well as V. Shpak, a leading social work specialist and psychologist, who worked at the Sviatoshynskyi District Center of Social Services for Families, Children and Youth in Kyiv. The number of surveyed participants is 12 people. The study was conducted in November-December 2020. During the focus group, the participants were also asked to fill in 2 tables "Semantic Differential Form" and "Repertory Grid Form", as well as a separate sheet with general questions related to the research topic.

Therefore, a focused group interview of the group №1 was conducted in order to explore the psychosemantic space of the Nesquik commercial video. The group №1 was also asked to fill in the "Semantic Differential Form" and the "Repertory Grid Form". The ratings of evaluation, potency and activity (EPA) were used in order to elaborate more explicitly the connotative value of a particular advertising video by the method of semantic differential.

\section{Results and Discussion}

Before analyzing the results of the answers, it is necessary to indicate the ideal model of the impact of video advertising, where the most effective advertising message is located in the upper corner of the chart on the right (Figure 1). 


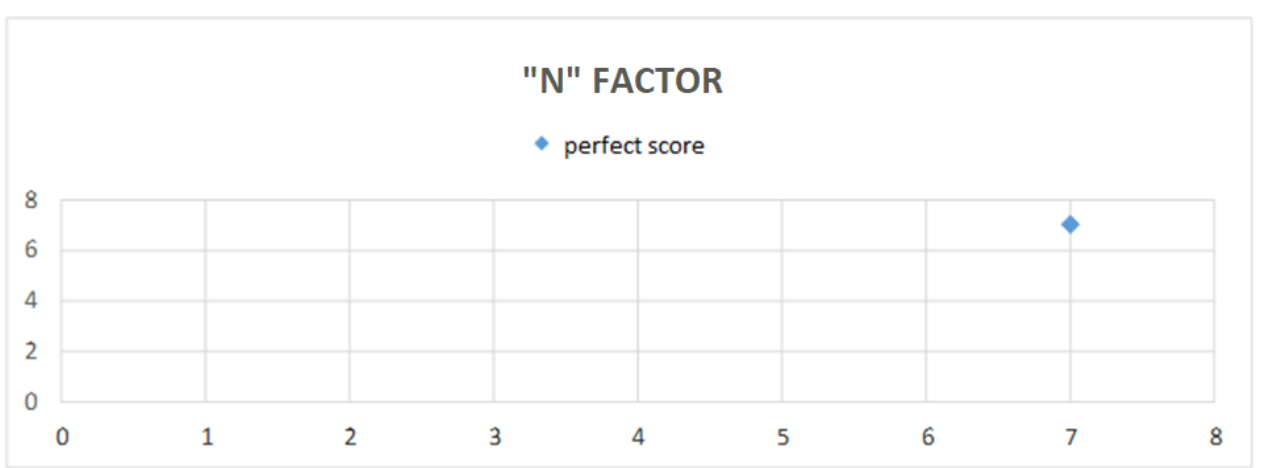

Figure 1. The ideal model of video advertising impact.

Source: Authors' computation

The response analysis of the group №1 showed that the average score on the factor "evaluation" is 5,3 (see Figure 2). This result shows that the attitude of the target audience to video advertising is close to positive, as the figure exceeds the average index, that is 4 , which is a neutral evaluation of the video advertising impact on the consumer.

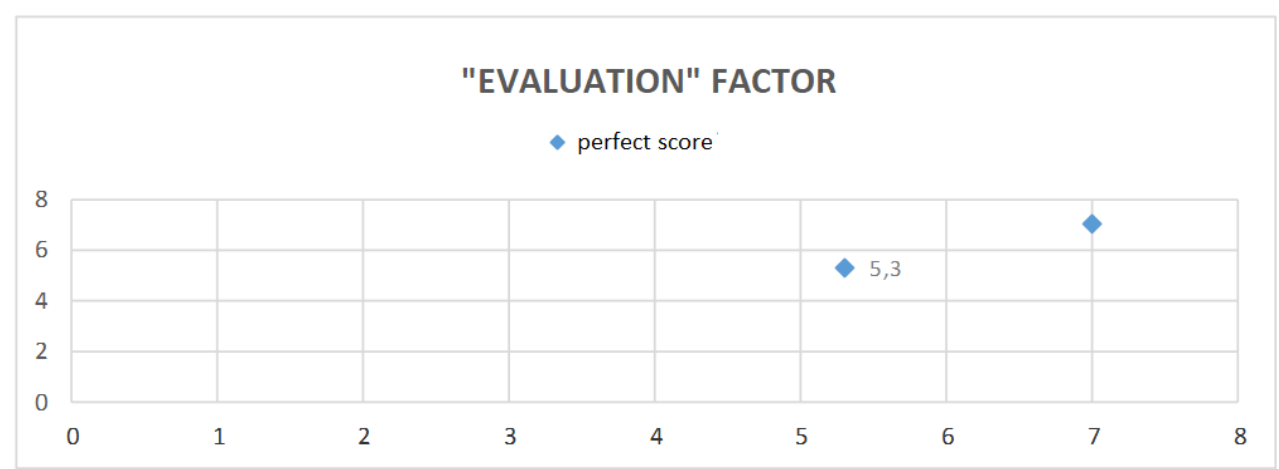

Figure 2. The "evaluation" factor of Nesquik commercial video advertising.

Source: Authors' computation

It was further determined that the average score of the "potency" factor is 5,8 (see Figure 3). This suggests that the level of impact of video advertising on recipients is significant and may induce them to consider purchasing goods.

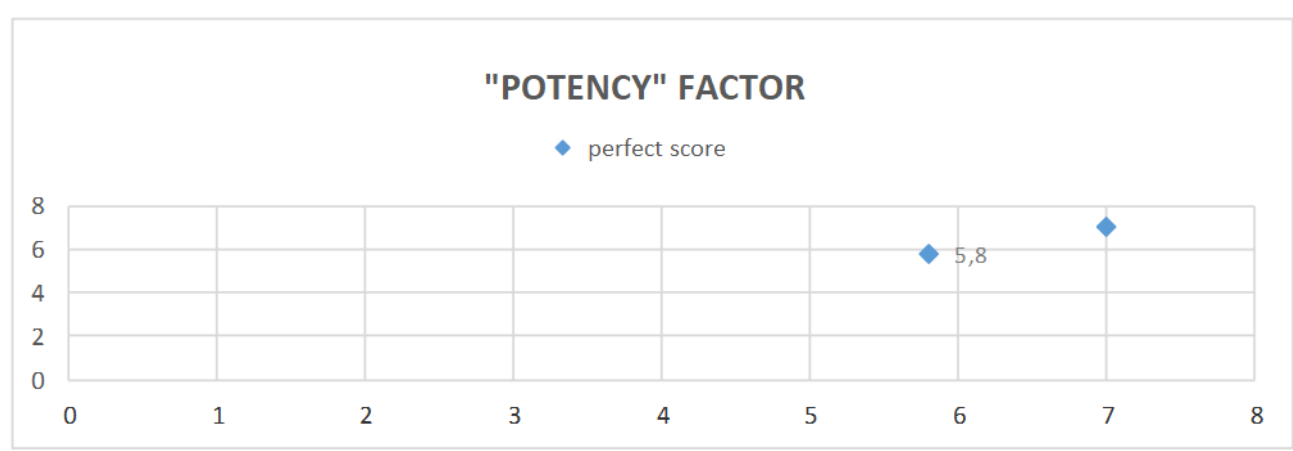

Figure 3. The "potency" factor of Nesquik commercial video advertising.

Source: Authors' computation

According to the results of the survey, the third "activity" factor showed an arithmetic mean value of 5,6 (see Figure 4). Thus, it can be affirmed that the video advertising actively encourages the consumer to act and has a strong motivational character. Moreover, the answers of group №1 in this category demonstrate the interest of viewers in the advertised product and the probability of potential purchase. 


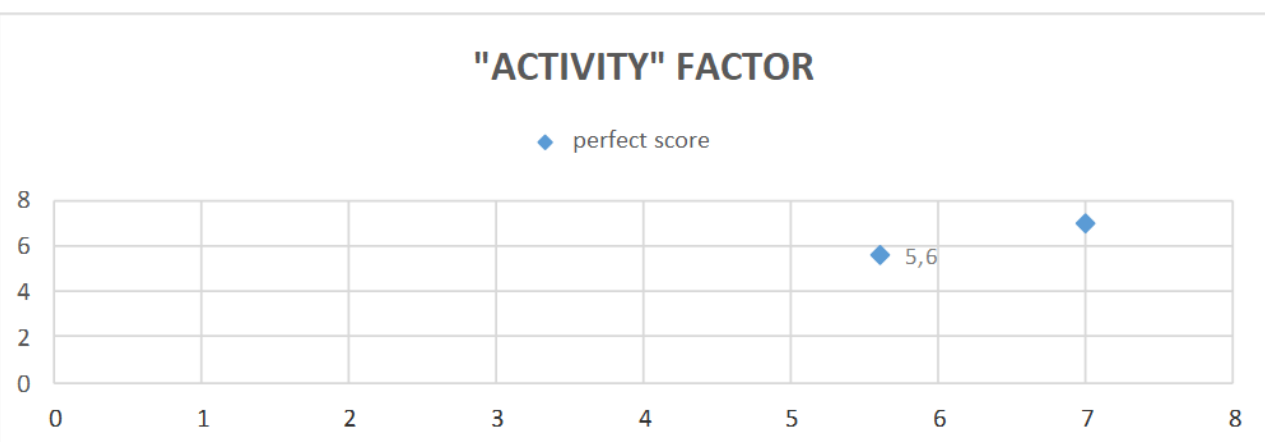

Figure 4. The "activity" factor of Nesquik commercial video advertising.

Source: Authors' computation

The results of the analysis show that Nesquik commercial video advertising performs its informative function at a high level and has a positive evaluation of all three factors among its target audience. It was decided to make a graph for assessing the impact of video advertising, where 4 is a neutral mark, in order to have more accurate analysis of the psychosemantic space of video advertising by the method of semantic differential (see Figure 5).

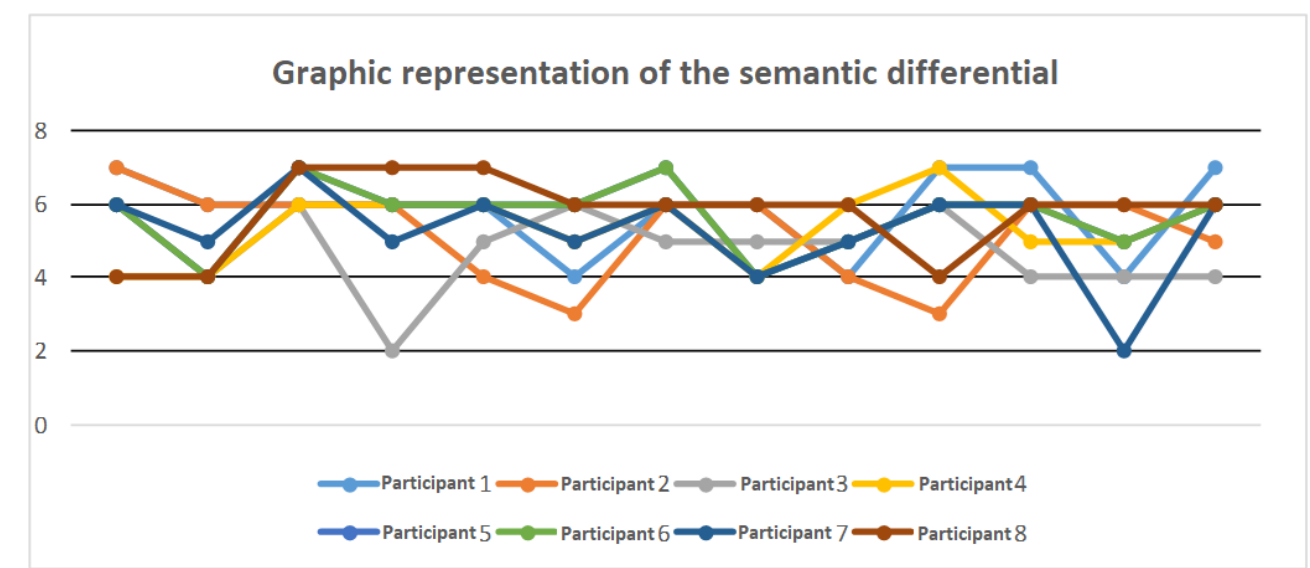

Figure 5. The semantic evaluation of Nesquik commercial video advertising. Source: Authors' computation

In this figure, it can be clearly seen that a larger percentage of responses are not on the mark «4». This indicates that video advertising has a positive evaluation by the method of semantic differential, and accordingly, it is a powerful tool in influencing the respondent's consumer behavior.

The next method that was used for the analysis of the survey results of the focus group №1 is the repertory grid technique. Data processing was as follows: determining the same and different indicators of the video advertising impact by dividing the scale with opposite adjectives into 3 factors (evaluation, potency, activity) and comparing their assessments of these factors. The average score of the response of each of 8 respondents on these factors was calculated by dividing the binary opposite values into categories (see Table 1).

Table 1.

The average value of Nesquik commercial video advertising on EPA factors.

\begin{tabular}{lllllllll}
\hline Factor & №1 & №2 & №3 & №4 & №5 & №6 & №7 & №8 \\
\hline Evaluation & 6 & 5,3 & 3 & 5 & 5 & 4,6 & 5,6 & 4,6 \\
Potency & 4,5 & 5,8 & 4,3 & 5 & 4,8 & 4,8 & 5 & 4 \\
Activity & 6,5 & 5,5 & 4 & 6 & 4,5 & 4,5 & 5,5 & 5 \\
\hline
\end{tabular}

Analyzing the results in the table, it can be stated that Nesquik commercial video advertising has a positive effect on its target audience on all three factors, as almost all results exceed the mark «4», 
which is a neutral value between the positive and negative effects of consumer influence.

These results show that the strong point of the Nesquik commercial video is its motivation for certain actions, in this case, its consumer encouragement to purchase the advertised product. However, the weakest point of the message is the power of influence on the viewer, since this indicates that such advertising is at risk of not being remembered by the recipient and there may be a high probability that the consumer will not watch the video advertising again.

The focus group №2 with teenage orphans was formed to establish the psychosemantic impact of
Coca-Cola corporate video advertising. This advertising was shown to the respondents, and as noted earlier, it is oriented towards this target group of consumers.

The next step was to analyze the answers of the "Semantic Differential Form" according to the EPA method. Thus, the arithmetic mean value of Coca-Cola corporate video advertising is 4,7 by "evaluation" factor (see Figure 6). This result indicates that the target audience has a positive attitude to the promotional video, but, compared to previous video advertising, this figure is much lower.

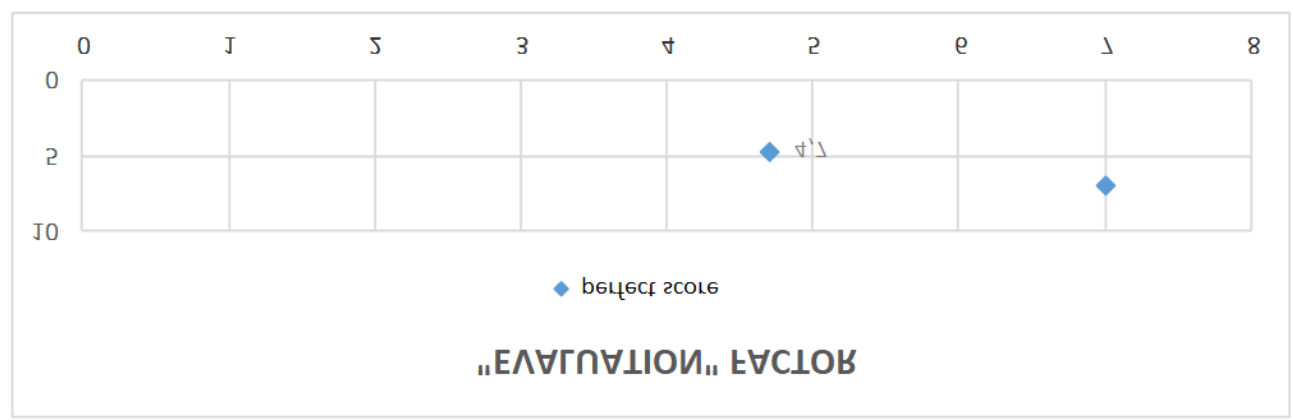

Figure 6. The "evaluation" factor of Coca-Cola corporate video advertising.

Source: Authors' computation

So, after that, the average score for the "potency" factor was set at 5,5 (see Figure 7 The "potency" factor of Coca-Cola corporate video advertising). This indicator demonstrates the effectiveness of the advertising impact of the Coca-Cola corporate video on the behavior of the individual, which is an important element in achieving the main concept of the message. The advertisement attracts viewer's attention and keeps it throughout the entire viewing of the message.

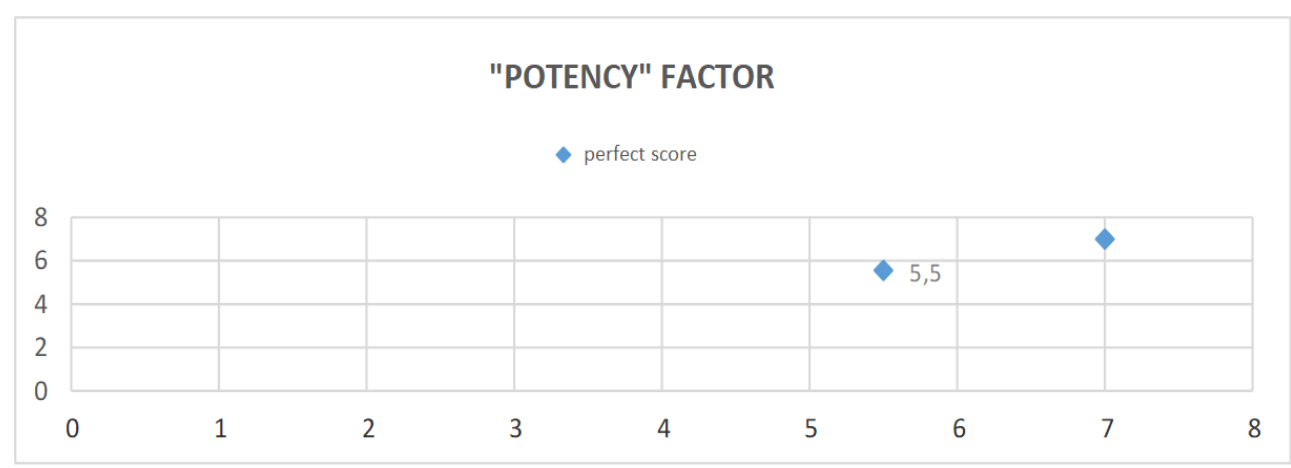

Figure 7. The "potency" factor of Coca-Cola corporate video advertising.

Source: Authors' computation

The last "activity" factor showed an average psychosemantic impact score of 5,4 (see Figure 8 ). This result suggests that corporate advertising can not only influence the opinions and values of the target audience, but it can also motivate to certain actions, in particular, in this case, it supports the brand's initiative to prepare entrants from orphanages for external independent testing. 


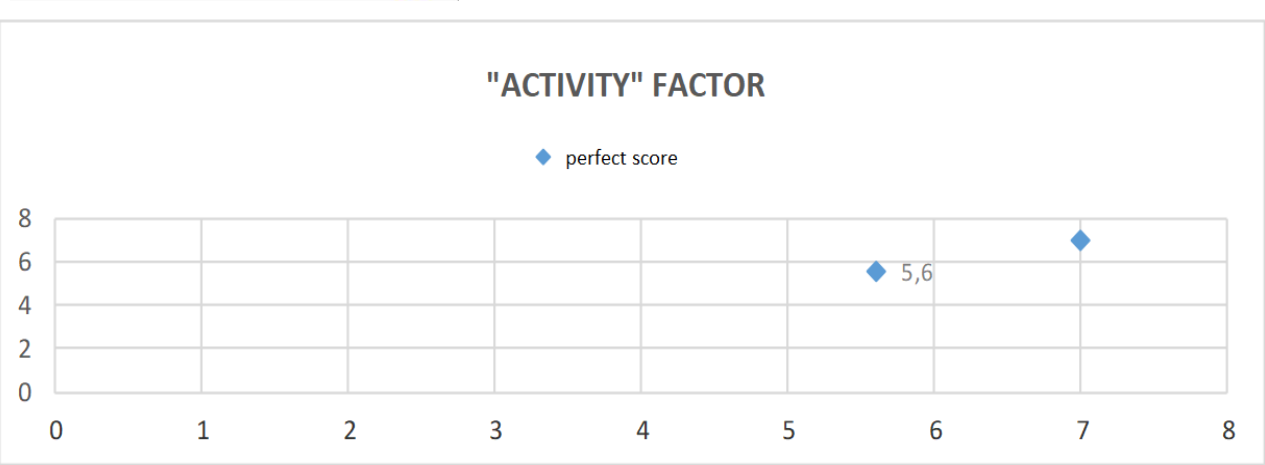

Figure 8. The "activity" factor of Coca-Cola corporate video advertising.

Source: Authors' computation

On the basis of the results obtained by mathematical and EPA methods, it can be determined that the Coca-Cola corporate promotional video has a strong impact on its audience. It clearly demonstrates the company's socially responsible activities and strengthens the moral principles of society in relation to the problem of orphanhood in Ukraine. Then the semantic evaluation was reproduced on a graphic image, which enables to visually draw conclusions about the effectiveness of the relevant advertising message (see Figure 9).

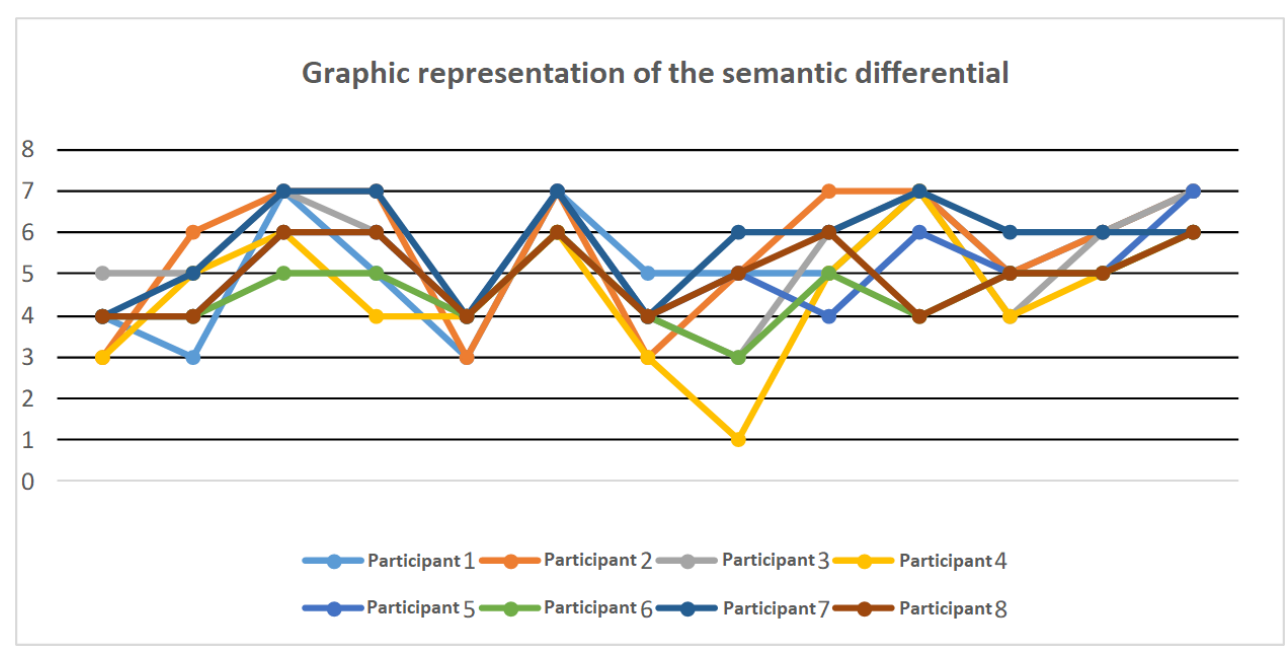

Figure 9. The semantic evaluation of Coca-Cola corporate video advertising.

Source: Authors' computation

This graph shows that most respondents identified Coca-Cola corporate video advertising as a powerful tool in influencing the psychological processes of human consciousness.

Then the group №2 filled in the "Repertory Grid Form", the analysis of which demonstrated the

Table 2.

The average value of Coca-Cola corporate video advertising on EPA factors.

\begin{tabular}{lllllllll}
\hline Factor & №1 & №2 & №3 & №4 & №5 & №6 & №7 & №8 \\
\hline Evaluation & 4,8 & 6,6 & 4,6 & 4,6 & 5,2 & 4,5 & 5,2 & 4,8 \\
Potency & 5,5 & 6 & 3,8 & 4,8 & 4,5 & 4,5 & 4,5 & 4,5 \\
Activity & 6,5 & 6,5 & 6 & 5,5 & 4 & 4,5 & 6 & 6 \\
\hline
\end{tabular}

psychosemantic features of the corresponding advertising on such factors as "evaluation", "potency" and "activity".

Thus, the test results, divided into three categories, showed the following numerical indicators of advertising impact on the consumer (see Table 2). 
By analyzing the results in the table, it can be stated that Coca-Cola corporate advertising has a positive impact on its target audience on all three factors, as almost all results exceed the mark «4», which is a neutral value between the positive and negative effects of consumer influence.

The next results of the study were obtained after the meeting with focus group №3, which was attended by 10 respondents at the age of 25-45 and 2 experts specializing in psychological sciences and advertising. During the focus group, 6 promotional videos were shown, including:

- McDonald's social video advertising;

- Roshen commercial video advertising;

- Coca-Cola social video advertising;

- McDonald's corporate video advertising;

- Roshen corporate video advertising;

- Nesquik corporate video advertising.

The respondents preferred the Coca-Cola social video among 6 viewed advertisements, because, according to them, compared to other advertising, it focuses on the most relevant issues and stands out for the way it presents information. More than $70 \%$ of respondents said that the emotional content of the advertisement is more important factor than the use of the information component, in particular, facts, knowledge about the product, service or problem.

Meanwhile, the results of the responses showed low interest and attention to corporate advertising. The participants noted that the meagre presentation of information does not trigger any emotions or arouse interest, which means that corporate video advertising is not very effective.

At the end of the discussion, each participant received "Semantic Differential Form" and "Repertory Grid Form" for each promotional video. However, the findings of the analysis are presented in a format that is different from the previous two focus groups. At this point, the assessment of psychological impact is determined not among individual respondents, but by comparing 6 promotional videos, which can clearly demonstrate the effectiveness of the impact on consumer of each of them.

So, the arithmetic mean value for each video advertising is presented in the table by the "evaluation" factor: McDonald's social advertising - 4,6; Roshen commercial advertising - 4,5; Coca-Cola social advertising 5,6; McDonald's corporate advertising - 3,5; Roshen corporate advertising - 4; Nesquik corporate advertising $-4,2$ (see Figure 10). The results show that the participants had the most positive attitude to the Coca-Cola social video advertising, in particular, the originality of the advertising message and its attractiveness were highlighted, while the respondents were least impressed by McDonald's corporate advertising, where the key elements are opposite factors such as banality and uninteresting submission of information.

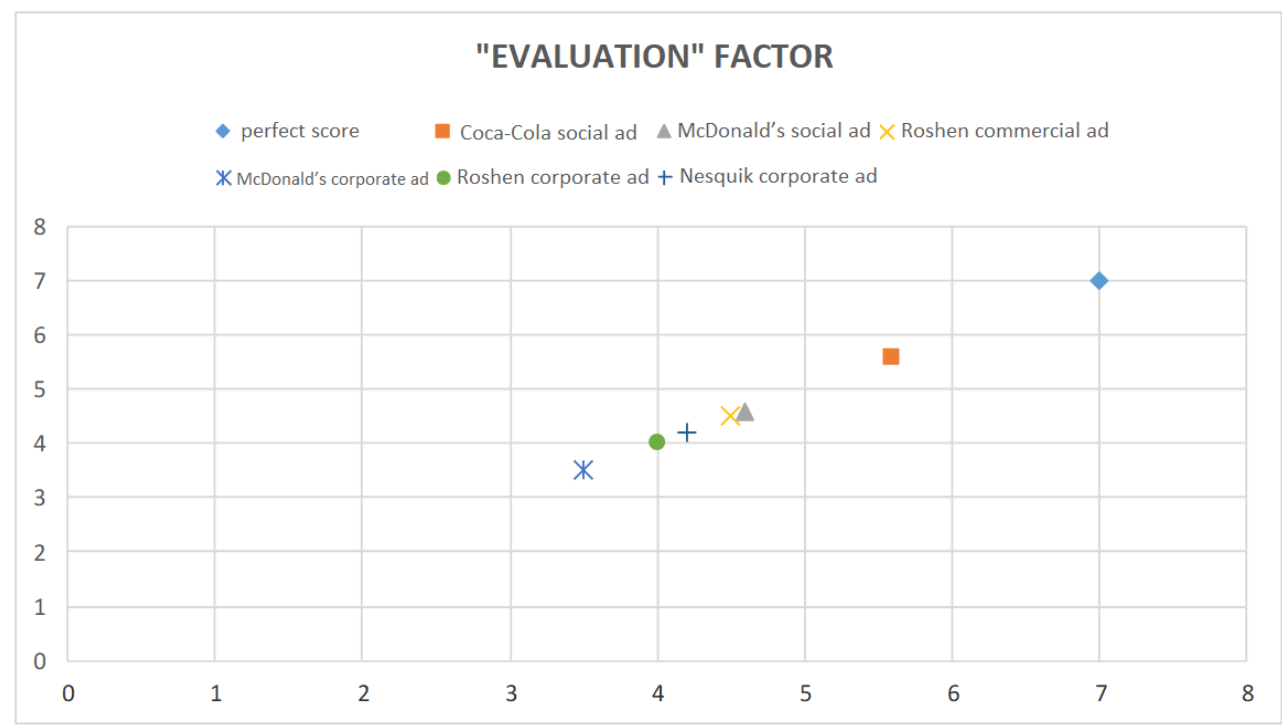

Figure 10. The "evaluation" factor of video advertising for the focus group №3.

Source: Authors' computation 
The analysis of the "potency" factor diagram shows that comprehensibility and relaxation can be important elements in the development and implementation of a potentially effective advertisement (Figure 11).

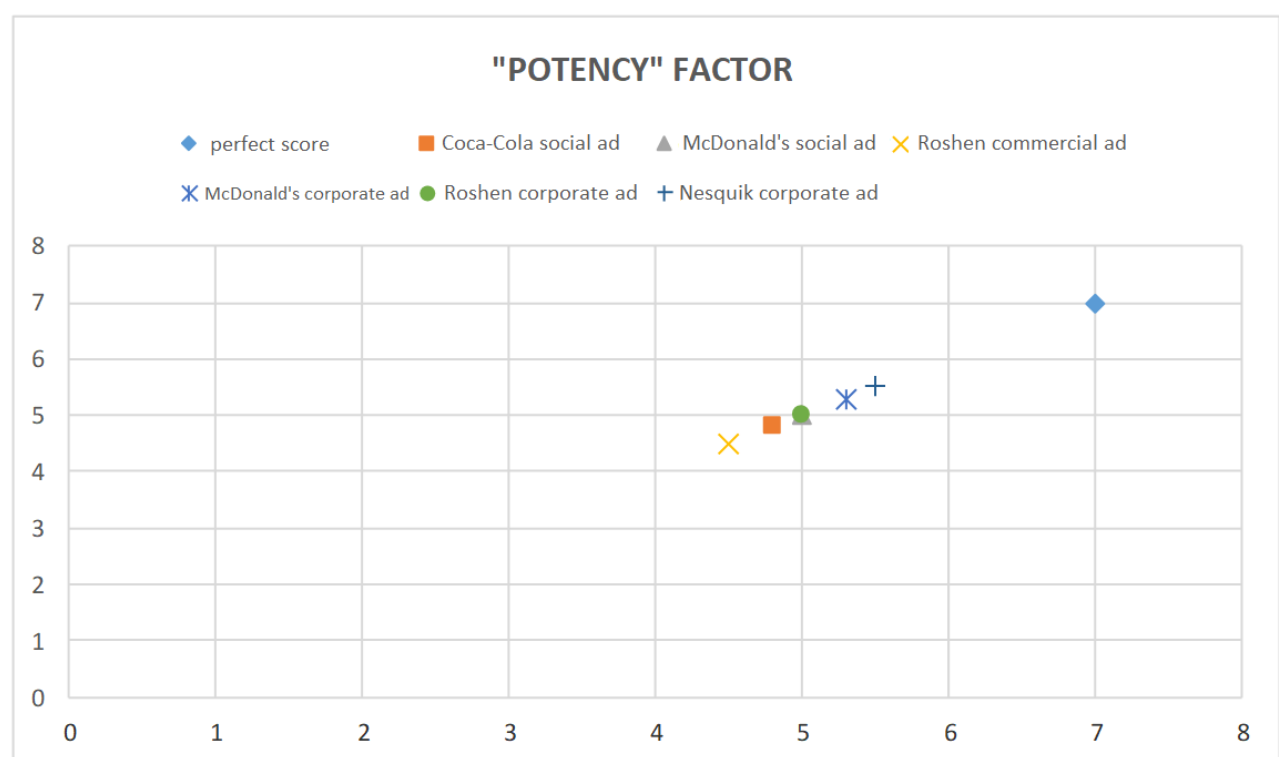

Figure 11. The "potency" factor of video advertising for the focus group №3

Source: Authors' computation

The "activity" factor for the sample of advertising messages determines the average values of the estimates in the table of semantic differential (see Figure 12). According to the results of the mathematical analysis, the lowest indicator of motivation for action was shown by McDonald's social video advertising, as the focus group participants identified the advertising message as the most intense and not clear enough. Coca-Cola social advertising took once again the first position as the most motivating information message for decisionmaking or action. Thus, it can be concluded that the light and calm video advertising is not an indicator of communicative effectiveness in influencing public awareness.

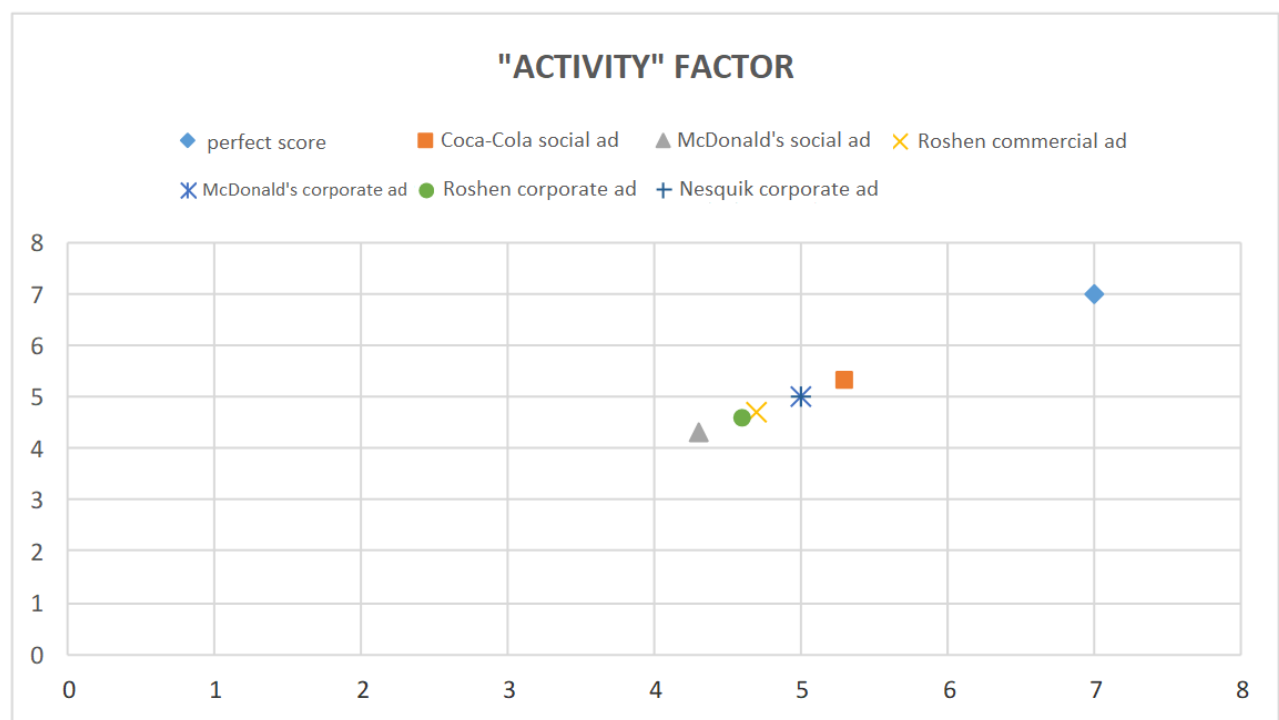

Figure 12. The "activity" factor of video advertising for the focus group №3 Source: Authors' computation

With the help of these visual schemes, it can be seen that Coca-Cola social advertising is the closest to the ideal rating in two cases among 6 promotional videos. It has shown the highest results in terms of consumer loyalty and encouragement to take certain measures to solve 
social problems. The next step of the analytical study was to establish an average score for all items of binary opposite adjectives for each individual video. That is why the results of each participant's survey were calculated and the overall average score of psychosemantic influence for social, corporate and commercial advertising was determined (see Figure 13).

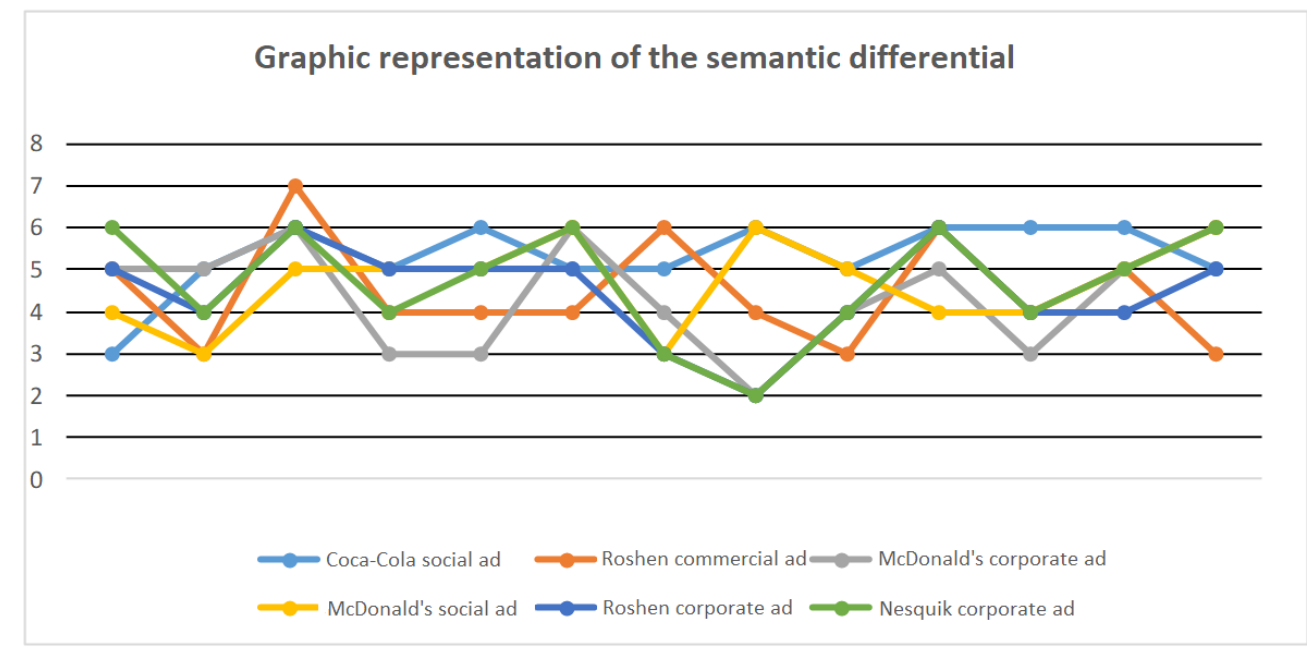

Figure 13. The semantic evaluation of video advertising for the focus group №3

Source: Authors' computation

The graph shows the dynamics of consumer's attitude to each particular advertisement. Nesquik and McDonald's corporate video advertising stand out the most among others, as the lines fall below the mark «4» several times. In general, the plane in this area means a negative and weak spectrum of influence on the individual. Whereas Coca-Cola social advertising demonstrates stable dynamics over almost all characteristics and keeps the equable trajectory in the positive plane of the graph.
"Repertory Grid Form" was the last table filled in by the group №3. The results of this survey can be viewed in the table below, where McDonald's social advertising is under №1, Roshen commercial advertising - №2, Coca-Cola social advertising - №3, McDonald's corporate advertising - №4, Roshen corporate advertising - №5, Nesquik corporate advertising - №6 (see Table 3).

Table 3.

The average value of Coca-Cola corporate video advertising on EPA factors.

\begin{tabular}{lllllll}
\hline Factor & №1 & №2 & №3 & №4 & №5 & №6 \\
\hline Evaluation & 4,3 & 3,5 & 4,8 & 4 & 3,8 & 4,5 \\
Potency & 4,5 & 4,3 & 4,5 & 3,8 & 2,8 & 3,5 \\
Activity & 5 & 4 & 5,3 & 4,5 & 4 & 4 \\
\hline
\end{tabular}

Source: Authors' computation

Based on the obtained values, it can be concluded that Coca-Cola social video advertising is highly effective form of impact on human consciousness in terms of George Kelly's repertory grid method. Its indicators demonstrated the high results of the effectiveness of advertising message among the target audience again. The second place was taken again by McDonald's social advertising message, which proves the effectiveness and reliability of this psychosemantic analysis method. The lowest result was shown by Roshen corporate video advertising, as the power of influencing the consumer's consciousness became an important element.

\section{Conclusions}

Thus, the conducted psychosemantic research has revealed certain features of video advertising perception by three segments of the Ukrainian audience. It was found that, children react most negatively to advertising messages, even those aimed at satisfying their consumer interest. It is also important to understand that when creating a promotional video that will be focused on the 


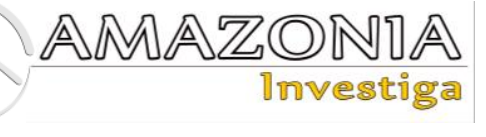

target children's audience, it is necessary to take into account such important factors as clarity and energy. The passive video advertising is not able to attract the child's attention, because such an age is characterized by hyperactivity on psychological and biological grounds, which is the complete opposite of such semantic meanings as calmness and obsession. The recommendation element will also be that the structure of the advertising message should be no more than 30 seconds, because this target audience quickly loses their interest due to the longevity of the source of information, and therefore, in most cases, the child will not finish watching the video.

The adolescent segment of the advertising market demonstrates a higher level of awareness of video importance for modern society. For this audience, the necessary elements of advertising are its reliability and informativeness, in particular, the results of our study have shown some of the highest indicators of the effectiveness of the impact on consumer consciousness. It was found that the youngsters best respond to video advertising that is more random in nature. It was studied that, unlike children, adolescents have already required the appropriate treatment of their personality by introducing not only an attractive visual image of video advertising, but also its semantic content.

During the study of the psychosemantic perception of video advertising, men and women at the age of 25-45 chose Coca-Cola social message as the most attractive among all three types of advertising samples. An important element of the effective impact of a social video is its coloristics, as all advertising is mounted in warm shades that help to dispose towards sociability. It was determined that McDonald's, Nesquik and Roshen have the weakest corporate advertising. Ukrainian viewers do not like clear manifestations of advertising messages while watching a show or, in our case, a morning TV show.

So, the conducted analytical and experimental study allows to form certain recommendations for improving the effectiveness of audio-visual communication in the field of advertising:

1) when developing and implementing a promotional video in the Ukrainian market segment, it is recommended to take into account the peculiarities of the perception of visual commercial, social and corporate video advertising by the audience, which were identified in this work;

2) it is recommended to use such visual and audio elements for creating video advertising that will form the desired image for professionals in this field of the advertised product or idea, for example, it is a good idea to invite celebrities or influential characters, to pick the appropriate coloristics that directly depends on the type of message, to apply dynamics or, on the contrary, a calm video sequence properly;

3) the positioning of new advertising videos will be more effective and successful if the correlation of the visuals with the audiovisual field existing in the advertising market is achieved during the process of their filling with audio and visual content.

\section{Bibliographic references}

Acharya, S., \& Shukla, S. (2012). Mirror neurons: Enigma of the metaphysical modular brain. Journal of Natural Science, Biology, and Medicine, 3(2), pp. 118-124. DOI: $10.4103 / 0976-9668.101878$

Antonides, G., \& Raaij, F. W. (1999). Consumer behavior: A European perspective. Journal of Consumer Policy, 22, pp. 375-392. DOI: https://doi.org/10.1023/A:1017285204683

Bart fink (2019). Roshen Dark Chocolate 2019 30 commercial [Video]. YouTube. https://www.youtube.com/watch?v=RfEf67 $\mathrm{Mu} 2 \mathrm{cw}$

Candy Industry (2020). 2020 Top 100: Exclusive list of the Top 100 candy companies in the world. Recovered from https://www.candyindustry.com/articles/889 64-top-100-exclusive-list-of-the-top-100candy-companies-in-the-world

Chandrasekar, C. (2018). How Digital Video Advertising Will Dominate the Next Decade. Search Engine Journal. Recovered from https://www.searchenginejournal.com/digital -video-advertisingdomination/256031/\#close

Chin, W., Johnson, N., \& Schwarts, A. (2008). A fast form approach to measuring technology acceptance and other constructs. MIS Quarterly Journal, 32(4), pp. 687-704. Recovered from https://www.jstor.org/stable/25148867?seq= 1

Coca-Cola Journey Ukraine (2020). Open as if for the first time [Video]. YouTube. https://youtu.be/yWxv3Mfke_w

Dushkina, M. (2021). Psychology of influence in social communications: psychological influence - methods and technologies. Moscow: Liters. 
du Plessis, E. (2009). Digital Video Recorders and Inadvertent Advertising Exposure. Journal of Advertising Research, 49(2), DOI: $10.2501 / \mathrm{S} 0021849909090345$

Horner, H. (2018). The Psychology of Video: Why Video Makes People More Likely to Buy. Sproutvideo. Recovered from https://sproutvideo.com/blog/psychologywhy-video-makes-people-more-likelybuy.html

Kantar Group and Affiliates (2020). BrandZ Top 100 Most Valuable Global Brands 2020. Recovered from https://www.kantar.com/campaigns/brandzdownloads/brandz-top-100-most-valuableglobal-brands-2020

Kosarevskaya, T., \& Kutkyna, R. (2009). Psychosemantic approach to the study of individual consciousness. Vytebsk: VNU named after P.M. Masherov

Kukuliar, A., Grishina, A., Chinarova, O. \& Achina, A. (November, 2019). Perception of social advertising on a value-semantic level by students of humanitarian orientations. SHS Web of Conferences 70, 06004. Trends in the Development of Psycho-Pedagogical Education in the Conditions of Transitional Society.

DOI: https://doi.org/10.1051/shsconf/2019700600 4

Lipovaya, O. (2015) Psychological characteristics of psychosemantic research in psychology: an historical survey. Bulletin of the Taganrog Institute named after A.P. Chekhov, 2, pp. 262-267. Recovered from https://cyberleninka.ru/article/n/psihologiche skie-osobennosti-psihosemanticheskihissledovaniy-v-psihologii-istoricheskiyobzor

Maksimova, L.A., Smirnov, A.V., \& Vasyagina, N.N. (July, 2019). Analysis of the psychosemantics of information environment among representatives of different age and sex groups. The European Proceedings of Social \& Behavioural Sciences EpSBS, pp. 334-342.

DOI: 10.15405/ epsbs.2019.07.43

McDonald's Ukraine (2020). The palm of happiness, \#bez_batkiv_niiak [Video]. YouTube.

https://www.youtube.com/watch?v=4prCkdgQUg

Morning with Ukraine (2020). Tips from Lilia Rebryk [Video]. YouTube. https://www.youtube.com/watch?v=M9MuR Z7x304

Nazarov, M., \& Papantimu, M. (2009). Visual imagery in social and marketing communication. Experience of interdisciplinary research. Moscow: Librokom.

Osvitoria (2019). Osvitoria and Coca-Cola are preparing for the external evaluation online in Transcarpathia [Video]. YouTube. https://www.youtube.com/watch?v=1rueqpbgps

Petrenko, V., \& Mitina, O. (2020). The Fairytale Semantic Differential Technique: A CrossCultural Application. Behavioral Sciences, 10(7), pp. 112. DOI: https://doi.org/10.3390/bs10070112

Smirnova, O.Yu., \& Serkin, V.P. (2020). The development and approbation of the semantic differential «a strong-willed person». Psychology, Journal of the Higher School of Economics, 17(2), pp. 210-222. DOI: 10.17323/1813-8918-2020-2-210-222.

Sosniuk, O. (2018). Psychosemantic analysis of the features of youth's representations about innovative brand. Ukrainian Psychological Journal, 4(10), pp. 141-155.

The Interactive Advertising Bureau (2020). IAB U.S. 2020 Digital Video Advertising Spend Report: Putting Covid in Context. Recovered from https://www.iab.com/wpcontent/uploads/2020/06/IAB_2020VideoAd Spend_FINAL.pdf

VideoAds (2018). Ukrainian advertising Nesquik [Video]. YouTube. https://www.youtube.com/watch?v=aFcupY $6 Z 93 \mathrm{k}$ 